\title{
Health Programme Evaluation and the Improvement of Quality of Care: An Orthogeriatrics Programme Case Study
}

\author{
David Pérez-Jorge ${ }^{1 *}$, Fernando Barragán-Medero ${ }^{1}$, Juan Manuel Herrera-Hernández ${ }^{1}$, \\ Selene Falcón-Chueca ${ }^{1}$ \\ ${ }^{1}$ Universidad de La Laguna (ULL), SPAIN
}

Received 24 January 2019 - Accepted 11 April 2019

\begin{abstract}
The evaluation results of the Orthogeriatric Unit at Nuestra Señora de la Candelaria Hospital, Tenerife, Canary Islands, are set out in this paper. The fundamental aim has been the assessment of comprehensive rehabilitation and the improvement of quality of life, which would allow a faster discharge process for patients over 65 years of age. A transversal and longitudinal assessment has focused on its aims and its results, the reference criteria or quality standards and the contributions made by the working team. The longitudinal analysis shows that the days in hospital are considerably reduced, surgical interventions have increased and the waiting time between admittance and surgery is reduced, and the prescription of a rehabilitation process after surgery and discharges has increased. The transversal analysis reveals differences in length of rehabilitation between the Orthogeriatric Unit patients and the outpatient alternative, proving that a significant improvement and optimisation has been achieved.
\end{abstract}

Keywords: orthogeriatric, care plans, programme evaluation, hospitalisation time

\section{INTRODUCTION}

Orthogeriatric Units (OU) in Spain are comprehensive functional rehabilitation units with multidisciplinary teams whose aim is to treat patients with hip fracture from immediately after surgery until the patient is discharged from hospital. They play a fundamental part in the patient's holistic rehabilitation as, together with the operation, they favour recovery of an optimum level of autonomy or at least a level similar to that before surgery.

These units were created as an alternative to the traditional healthcare model (Pioli et al., 2008) and its teams comprise Orthopaedic Surgeons, Rehabilitators, Anaesthetists, Geriatricians and nurses, as well as other collaborating professionals, such as physiotherapists and social workers. Depending on where the programme is established, there may be variations in the Orthogeriatric teams, and there may also be occupational therapists (Agency for Clinical Innovation, 2010). It is interesting to emphasise that seen from an ethical (healthcare) point of view, there is a demand for an analysis of the differences in gender and of the essential need to add educators to multidisciplinary teams (Barragán, 2016).

Orthogeriatric Programmes (OP) mostly treat the elderly who are admitted into the orthopaedic unit due to a hip fracture of diverse aetiology. These fractures are mostly produced by osteoporosis (predisposing factor) and falls (precipitating factor) (Sociedad Española de Geriatría y Gerontología, 2007).

Since February 2013, Nuestra Señora de La Candelaria University Hospital (HUNSC) has conducted an OP to improve the quality of life before discharge of patients who are over 65 years of age. Results show that implementation of the OP in the case of hip fractures has reduced the recovery time of these patients by up to $30 \%$ (Cruz \& Lillo, 2015).

(C) 2019 by the authors; licensee Modestum Ltd., UK. This article is an open access article distributed under the terms and conditions of the Creative Commons Attribution License (http://creativecommons.org/licenses/by/4.0/).

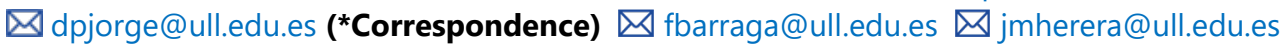




\section{Contribution of this paper to the literature}

- The findings attest to a greater quality of care in rehabilitation, establishing a better cost-benefit ratio in public healthcare and improved quality of life for patients due to a shorter time spent in hospitals and a faster recovery. They also highlight the relevance of multidisciplinary collaboration between healthcare and education professionals. New fields of work for education professionals are established in hospitals. Alternative approaches are essential for the future when we consider the "ageing" populations of Europe and higher life expectancies in a country like Spain.

- $\quad$ This paper will open up new paths in the application of this type of programme and will allow us to obtain better results in relation to the quality of life of patients.

\section{LITERATURE REVIEW}

\section{Putting Orthogeriatric Programmes into Practice}

A hip fracture is the most serious osteoporosis complication and is a consequence of thinning and weakened bones (Bardales et al., 2012), and is characterised by the progressive loss of bone mass, making bones become more porous and therefore more fragile, thus increasing the risk of fractures (Sánchez-Ocaña, 2010). Although it is an illness that affects older people, it is generally women who are at greater risk of suffering it after the loss of bone mass caused by the decrease in oestrogen in their bodies, due to menopause (Sánchez-Ocaña, 2010). According to Cruz and Lillo (2015, p.44) hip fractures are "one of the main causes of morbidity in elderly people, which means a great impact on society. [...] 85\% of all hip fractures occur in people over 65 years old".

The establishment of this type of programme allows one to obtain better results in the patients' recovery time by also reducing the average number of days spent in hospital and of the time waiting for surgery. The speedy recovery of patients and the reduction of the average number of days spent in hospital mean an important reduction in hospital costs (Cruz, 2016; Miura et al., 2009). The positive effects of a multidisciplinary approach to rehabilitation processes in elderly patients are fundamental (Cruz \& Lillo, 2015), since according to studies, such as those by Handoll and Sherrington (2007), Hoeing et al. (2006), and the National Clinical Guideline Center (2011), it leads to a considerable reduction in the time spent in hospital and "the burden on caregivers" (Cruz \& Lillo, 2015, p.44).

A study by Montalvo et al. (2011) revealed that those patients who were admitted into the OU were discharged earlier and experienced a significant functional improvement compared to those patients who were not included in the OP. This fact meant a reduction of hospital costs by between 8 and 19\%, as well as greater and faster movement autonomy (González-Montalvo et al., 2009). If we consider the outcomes at one of the biggest Orthogeriatric Units - Hospital La Paz, Spain, created in 2007, which treats an average of between 400 and 600 hip fracture patients a year (Europa Press, 2009) - we see that, in the opinion of its specialists, it is possible to "recover function, reduce hospital mortality, in the shortest time and at the lowest possible cost" (Europa Press, 2009).

As well as cost reductions, implementation of the multidisciplinary intervention programme by the OUs shortens the length of hospital stays and consumes fewer hospital resources; there are fewer complications and it adapts well to diagnostic and therapeutic indications and planning for an early discharge. As stated by Baztán et al. (2004), this has been made possible thanks to the introduction of tasks such as: a) Early intervention, b) Assessment of the functional and mental situation, the prognosis for recovery and the need for post-acute care, c) Assessment of the social situation and planning the necessary resources on discharge, d) Review and update of the plan of care, e) Coordination between the outpatients health and social services, f) Informing the family or caregiver about the needs and the care required by the patient after discharge (Falcón, 2014).

However, if we consider gender sensitivity ${ }^{1}$ (Justice European Commission, 2015) when analysing the phenomenon of longevity and the elderly (Barragán, 2016), some people have pointed to the existence of a double standard of ageing (Berman et al., 1981; Hyde, 1995; Sontag, 1972).

\section{The Orthogeriatric Programme at Nuestra Señora de La Candelaria University Hospital}

Since the implementation of the Orthogeriatric Unit at HUNSC in 2013, significant results have been achieved in relation to the length of hospital stay and recovery from injuries. In this programme, the multidisciplinary team which cares for the patient is responsible for organising and advising on the discharge of the patient from hospital

\footnotetext{
${ }^{1}$ Gender Sensitivity encompasses the ability to acknowledge and highlight existing gender differences, issues and inequalities
} and incorporate these into strategies and actions. 
to his or her home, providing available resources so as to make the return home as well adapted to their physical and health situation as possible

A social/family assessment is undertaken previously, not only to foresee the possible difficulties that the patient could have after discharge, in accordance with the support he or she may have, but to also determine the degree of autonomy before the fracture, and to see if the profile is suitable for candidates who can take part in the OP at HUNSC (Agency for Clinical Innovation, 2010; Falcón, 2014).

\section{The implementation of the $\mathrm{OP}$}

In practice, as is set out in the protocols for intervention, the patients who are selected to take part in the programme undergo surgery within 24-48 hours after being admitted, and if it is possible, the patient will get out of bed 24 hours after surgery and sit in an armchair so that the rehabilitation and recovery can begin in the next few hours (Pajulammi et al., 2017). After surgery and once the patient is stable, he or she is sent to an Orthogeriatric Unit where there are geriatric and rehabilitation doctors. These programmes enable the patient to have more rehabilitation sessions, thus improving functional movement and independence in daily life, decreasing both the time spent in hospital (Cruz \& Lillo, 2015; Sierra et al., 2017) and the future complications resulting from the surgical intervention (Marrero \& Lillo-Crespo, 2015; Suárez et al., 2017).

In general, the objectives of the OU at HUNSC, and following the guidelines established by the Department of Health of the Government of Western Australia (2008), are:

- Improving the health and general well-being of elderly people who have suffered hip fractures or are at risk.

- Optimise resources so as to reduce healthcare costs.

Given the characteristics of the study that we are presenting and of the objective which has oriented it, we have to justify its interest by the need to know the effectiveness of the programme carried out at HUNSC. During the implementation of a programme, and especially when it finishes, it is essential to carry out an evaluation which will allow us to obtain information about its value, planning, execution and the impact it had on the target groups, so that it can be used to make decisions that will allow future improvement (Fernández et al., 2012). Along these lines and as stated by Cruz and Lillo $(2015$, p.50) "multidisciplinary work, coordination and creation of protocols" are necessary for pathologies or orthogeriatric injuries, to avoid injuries associated with prolonged immobilisation; a prompt and well-planned return to their routine and daily environment prevents the appearance of future difficulties and complications (Falcón, 2014; Ortiz et al., 2008).

The assessment of the OP carried out at HUNSC during the period between 2013 and 2015 has enabled us to reflect on the data collected and analysed (Herrera, 2012). It will enable us to recommend the possible ways of refocusing deficiencies (Fernández \& Ares, 2002) through pre-established quality criteria (García \& Martínez, 2012).

What is intended with this type of assessment is to obtain conclusive information on the efficiency of the programme, verifying if the expected results are being achieved or not, according to the objectives formulated in the design (Fernández et al., 2012). The results obtained with this assessment will allow value judgements on the efficacy, effectiveness, efficiency and impact of the programme (Alonso et al., 2008, Martos et al., 2010; Tang, 2017).

The following evaluative activities must be taken into account (Rebolloso et al., 2008): a) analysis of the efficacy: it is conducted according to the set objectives, b) analysis of the efficiency: it refers to the intended and unintended effects that have been obtained with the programme, c) analysis of the efficiency: it refers to costs/benefits, costs/effectiveness, costs/usefulness, d) analysis of the effects beyond results, being understood as the effects with an impact not only on the recipients, but also on the general population that is not in the programme.

To be able to conduct the evaluation, it is necessary to design or present the indicators which will allow an analysis of the tendencies and of the evolution of the problem (Rebolloso et al., 2008).

\section{Quality indicators}

Within the field of evaluation, consideration must be given to quality, which refers to all those ways with which an organisation satisfies the needs and expectations of all the agents implicated, whether they be users, workers, financial enterprises that are involved, or society in general (Herrera, 2012).

The term "quality" means a set of characteristics of a specific service which fulfil the expectations of the recipient, satisfying his/her needs (Fernández et al., 2012). Good quality healthcare provision consists of correctly doing what has to be done in each case or process, performing it at the lowest possible cost and generating great satisfaction in those people who receive care (Ceballos, 2010).

In particular, in the field of healthcare, in order to determine the adaptation of healthcare services to the needs of the recipients and levels of excellence, the participation of professionals who provide medical assistance, health managers, and care receivers is required (Ceballos, 2010). 
In order to manage quality, there are instruments developed by certain bodies and organisations which establish the requirements to be satisfied by a particular product or service. One of the most prominent instruments are ISO standards (International Organization for Standardization), and it is the family of ISO 9000 standards that guarantee quality within different organisations (Fernández et al., 2012).

The ISO 9001 standard is an international regulation which describes what a quality management system should have, without specifying how it has to be implemented and developed. This allows us to maintain a certain flexibility to adapt the standard to the characteristics of the organisation in which the action is implemented (Ceballos, 2010).

In 2000, the International Organization for Standardization published the documents concerning the new ISO 9000 standards, which include the principles of a quality management system, ISO 9001 standards, which contain the specifications which must be fulfilled by a quality management system, and ISO 9004 which develops the guidelines to improve quality (Cánovas \& Pardavila, 2004). The ISO 9001:2008 quality management standard is particularly noteworthy in the field of health and other social protection systems (Herrera, 2012).

Since 2006, the University Hospital of Nuestra Señora de Candelaria (UHNSC) has had its own Integrated Management System, according to the ISO 9001:2008 standard, obtaining the European Quality label and the corresponding certification.

These quality management standards are based on the following principles (Fantova, 2005, p.345): a) Organisation focused on the customer, b) Leadership, c) Participation of the professionals involved, c) Approach based on processes, d) Approach of the system towards management, e) Continuous improvement, f) Approach based on facts in decision-making, g) A mutually beneficial relationship with the provider.

The certification ensures that the service meets the requirements established by the corresponding standards. Moreover, there exist two institutions which are responsible for this process: the National Accreditation Entity (ENAC) and AENOR, an entity responsible for the development of standardisation and certification in all industrial and service sectors.

In the field of quality, special mention should be made of excellence, seen as a remarkable and excellent manner of managing the organisation and obtaining the best possible results, taking into account the user's satisfaction, the management of all the processes and the optimisation of resources (Fernández et al., 2012).

The most important and frequently used excellence model is EFQM (European Foundation for Quality Management), created in 1988. Its primary purpose is to promote the excellence of European organisations, increasing, in this sense, their international presence (Cánovas \& Pardavila, 2004). This model tries to increase the effectiveness and efficiency of organisations, reinforcing quality and stimulating continuous development (Fernández et al., 2012).

\section{EFQM Model}

EFQM Excellence Model is intended to be a flexible model which can be applied to both large and small organisations in the public and private sector (Fantova, 2005). This model presents the following main ideas (Fantova, 2005, p.347): a) The aim of zero defects, b) The involvement of people in the organisation in decision making, c) The elimination of wasteful activities, d) Teamwork, e) Flexibility, f) A closer relationship with providers (this implies a system called just in time), g) Continuous improvement.

EFQM Model meets all the appropriate conditions for introduction in social healthcare systems since it allows us to evaluate and know the users' level of satisfaction. Moreover, it is not only limited to the control and standardisation of the regulation (Fernández \& Ares, 2002).

The University Hospital of Nuestra Señora de Candelaria (UHNSC) performs the self-assessment of the EFQM Excellence Model with the aim of improving the scientific and technical quality of the different services and increasing the level of satisfaction of the users of the service, adding value to the results obtained and helping to improve the patients' wellbeing.

Another aspect to be taken into account when we evaluate a program of this kind is Evidence-based practice (EBP), a method in which professionals must base their interventions on their professional experience, with scientific evidence in their investigations (Pereñíguez, 2012).

\section{Evidence-based practice}

Evidence-based practice (EBP) appeared for the first time in the field of Health Sciences, and is defined by medical experts as "the conscious, sensible and precise use of the best scientific and clinical evidence available to make decisions about the care of each patient" (Sackett, Rosenberg, Gray, Haynes, \& Richardson, 1996, p.71). EBP lets us base professional practice on interventions or programmes which imply the delivery of better healthcare services, from findings which empirically demonstrate that such actions produce effective and efficient results (Pereñíguez, 2012). 
In this sense, Evidence-based Medicine helps develop a method which aims to transform clinical data into scientifically valid knowledge, in order to make healthcare professionals apply the results obtained in scientific research, their professional experience and skills with the aim of improving the quality of medical practice (Vegade Céniga et al., 2009).

Some reasons which can be found to put into practice Evidence-based Medicine are cited below (Vizoso \& Caballer, 2005, p.29): a) The enormous variability of clinical practice, b) The variation in the use of health resources, c) Knowledge about the real benefit of new technologies, d) The increase in health expenditure, e) The overload of scientific information, f) The increase in the demand for health services. This requires a balance among equality, effectiveness and quality.

\section{OBJECTIVES OF THE STUDY}

\section{General Objective}

- To analyse the results and effects of the Orthogeriatrics Programme (OP), from its implementation in 2013 to 2014 .

\section{Specific Objectives}

- To obtain a profile of those patients who participated in OU.

- To perform a longitudinal and cross-sectional analysis to prove if the selected indicators have been modified over time and if the objectives of the programme have been achieved.

- To learn the opinions of the professionals involved about the functioning and effectiveness of the programme.

- To identify the weaknesses of the programme so as to improve service.

\section{METHODOLOGY}

\section{Sample}

In order to perform this research, we selected three different samples: a sample of 10 patients who did not participate in this programme since they had been operated on before the introduction of the programme in the hospital, a second sample made up of 130 voluntary patients who were admitted to UHNSC from 2013 to 2014 for hip fracture and who participated in the programme performed in this hospital facility, and a third sample made up of the professional staff who applied the programme $(\mathrm{N}=7)$. This sample was formed by three traumatologists, two nurses who provided the continuity of care, a physiotherapist, two internal medicine physicians and a social worker.

\section{Instruments, Procedure and Data Analysis}

This research was carried out in the first two years of the implementation of the programme in UHNSC, precisely from February 2013 to February 2015.

To gather information for this study, semi-structured interviews were held with the professionals in which they were asked about: a) utility and benefit for patients of the OP implemented by HUNSC; b) compliance with the objectives of the OP; c) their assessment of the coordination of the professional team linked to the OP; and d) potentialities and aspects of the OP requiring improvement (Falcón, 2014).

In addition, an ad-hoc questionnaire was conducted to assess the patients' experience; it covered independent variables (age, cohabitation unit, types and frequency of support, formal support prior to hospitalisation, formal support arranged by the HUNSC Social Services Unit) and dependent variables from each of the following studies:

Longitudinal analysis (data prior to the programme and data from the first year of operation of the programme): a) days of hospital stay; b) surgical intervention; c) waiting time in days from admission to surgical intervention; d) rehabilitation process; and e) discharge.

Cross-sectional analysis (only with data from the first year of operation of the programme): a) waiting time in days from surgical intervention to the beginning of rehabilitation; b) days of home care; c) waiting time in days from surgical intervention to transfer to Orthogeriatrics Unit; d) waiting time in days from surgical intervention to social assessment request; and e) days in Orthogeriatrics Unit. 
Table 1. Distribution of the sample according to sex and age

\begin{tabular}{|c|c|c|c|c|c|}
\hline \multicolumn{3}{|c|}{ Women } & \multicolumn{3}{|c|}{ Men } \\
\hline Age & Frequency & $\%$ & Age & Frequency & $\%$ \\
\hline $63-65$ & 3 & 2.0 & $60-65$ & 4 & 13.3 \\
\hline $66-80$ & 28 & 28.0 & $66-80$ & 16 & 53.3 \\
\hline $81-85$ & 30 & 30.0 & $81-85$ & 8 & 26.7 \\
\hline $86-90$ & 23 & 23.0 & $86-90$ & 2 & 6.7 \\
\hline $91-97$ & 17 & 17.0 & - & - & - \\
\hline Total & 100 & 100 & Total & 30 & 100 \\
\hline
\end{tabular}

Table 2. Distribution of the sample according to cohabitation unit

\begin{tabular}{lccccc}
\hline & Women & & & Men & \\
\hline Cohabitation Unit & Frequency & \% & Cohabitation unit & Frequency & \% \\
\hline Single woman & 37 & 37.0 & Single man & 7 & 23.3 \\
\hline Spouse & 11 & 11.0 & Spouse & 15 & 50.0 \\
\hline $\begin{array}{l}\text { Spouse e } \\
\text { Sons/daughters }\end{array}$ & 8 & 8.0 & $\begin{array}{c}\text { Spouse e } \\
\text { Sons/daughters }\end{array}$ & 5 & 16.7 \\
\hline Sons/daughters & 32 & 32.0 & Sons/daughters & 1 & 3.3 \\
\hline Others & 12 & 12.0 & Others & 2 & 6.7 \\
\hline
\end{tabular}

Firstly, a longitudinal analysis was carried out with the aim of determining the differences in autonomy and functionality achieved by those patients who had not participated in such a programme (before 2013) and those patients who participated in the programme in order to prove if there was an improvement as regards the objectives previously described.

Secondly, a cross-sectional analysis was performed to determine, through the data obtained from the database of the Social Work Unit (SWU), if the programme was fulfilling the proposed objectives.

In order to obtain these data, both patients' records, taken from SWU in UHNSC, and patients' clinical records regarding their hospital admission for hip fracture in that hospital, were analysed.

After requesting permission to perform this study, a documentary analysis of the patients' records, taken from the database of SWU in the hospital and UHNSC, was carried out.

Furthermore, some interviews were conducted with the different professionals and a questionnaire was also administered with the aim of ascertaining their views on the functioning of the programme and the results obtained. The questionnaire included some aspects to assess the level of usefulness and benefit of the programme for the patient and its degree of compliance. Furthermore, an open question was included in the questionnaire in order to reflect the aspects which could be improved.

The data collected were statistically processed and analysed through the Statistical Package SPSS V.25.

\section{FINDINGS OF THE STUDY}

The results, grouped according to gender, are outlined below. The socio-demographic profile is taken into account for each group. The last paragraphs in the results section include the opinions of professionals, which were taken from the interviews. See the distribution of patients in Tables $\mathbf{1}$ and $\mathbf{2}$.

As regards the profile of patients who received care in the programme, we can state that the largest group of women that received care were 81-85 years old (30\%), as compared to men, who were between 66 and 80 years old $(53.3 \%)$.

As regards the cohabitation unit, it was observed that single women were the largest group (37.0\%), compared to $50 \%$ of men who lived with their spouses.

In relation to the type of support received, the percentage of women who have informal supports, (support from family, friends, etc.) and previous formal supports (acquired privately or requested through official bodies such as the Home Help Service (HHS), places in Day Care Centres, etc.) is higher than that of men. After being discharged from hospital, $40 \%$ of women asked for formal support as compared to $36.7 \%$ of men. See Figure 1 . 


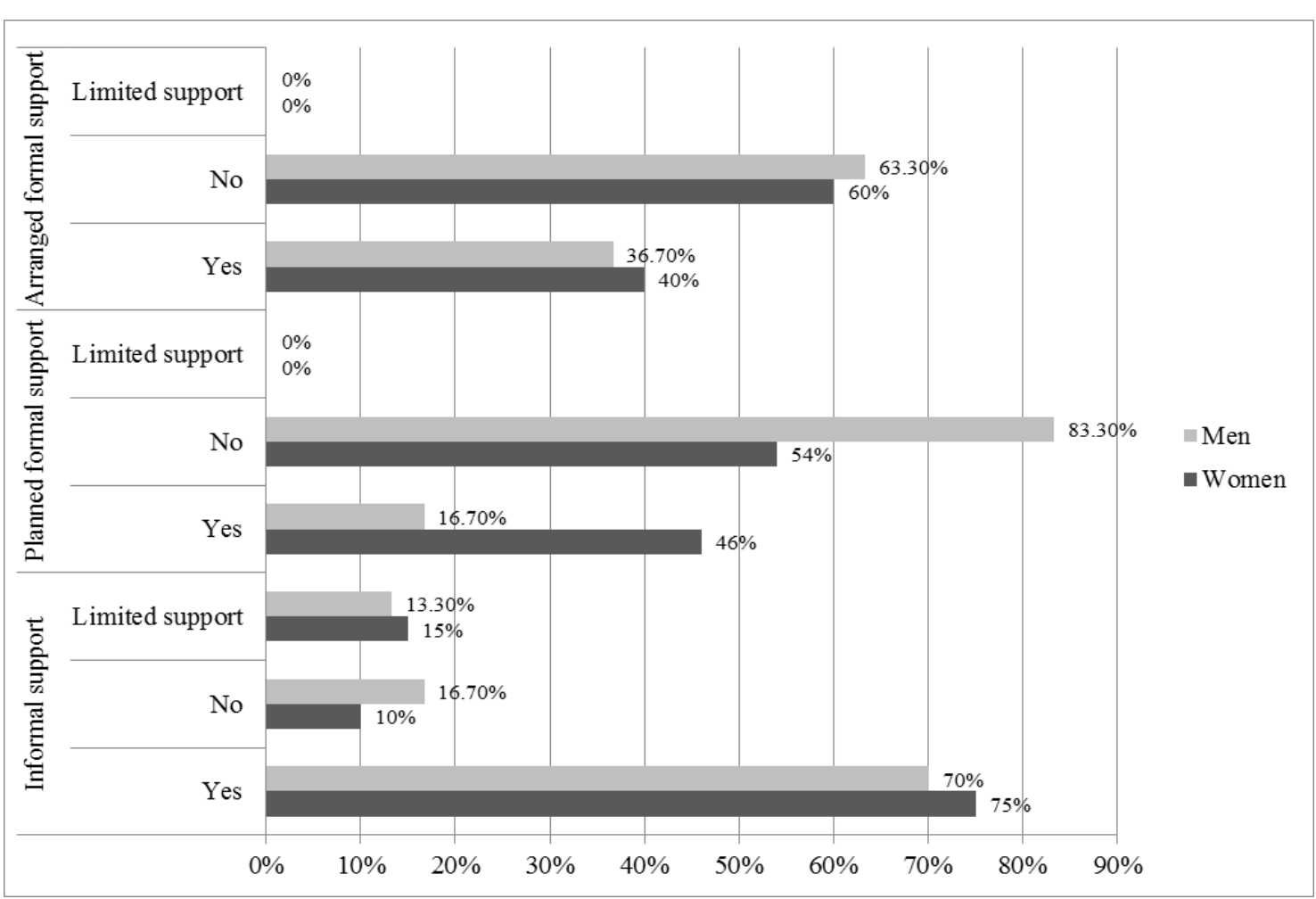

Figure 1. Kinds of support as regards gender

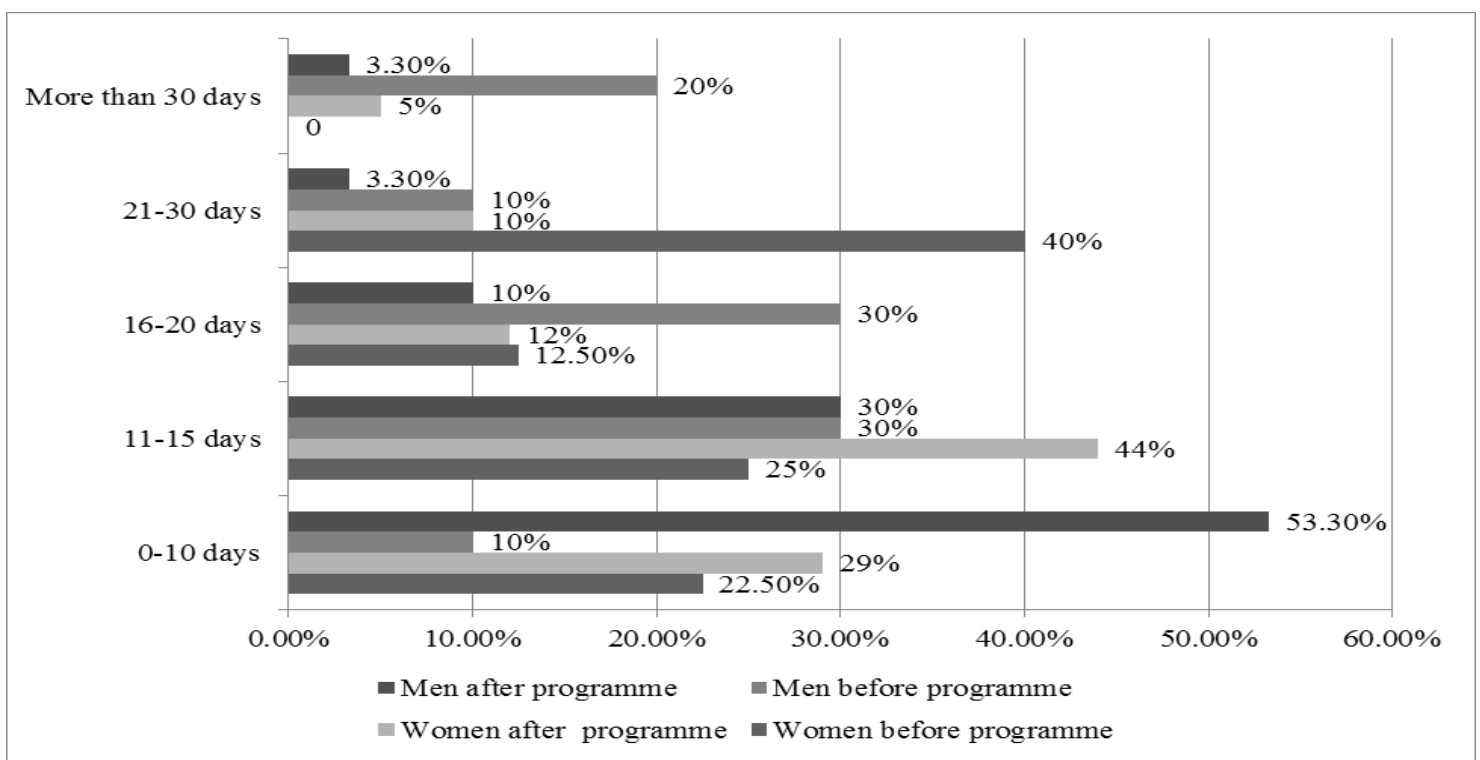

Figure 2. Days of hospitalisation before and after the implementation of the programme, according to gender

As regards the analysis of the days of hospitalisation before and after the implementation of the programme (longitudinal analysis), we could observe that before the implementation of the programme, $40 \%$ of women were in hospital from 21 to 30 days, whereas now $73 \%$ of female patients were in hospital from two to 15 days. At present, only $5 \%$ of women are in hospital more than 30 days. As regards male patients, $50 \%$ were in hospital more than 16 days before the implementation of the programme. However, after its implementation $53.3 \%$ were in hospital less than 10 days. See Figure 2.

The implementation of the programme has decreased the time spent in hospital. This fact, therefore, has resulted in an increase of the number of surgical interventions and a decrease of the waiting time from the hospital admission up to the moment of the intervention. See Figure 3. 


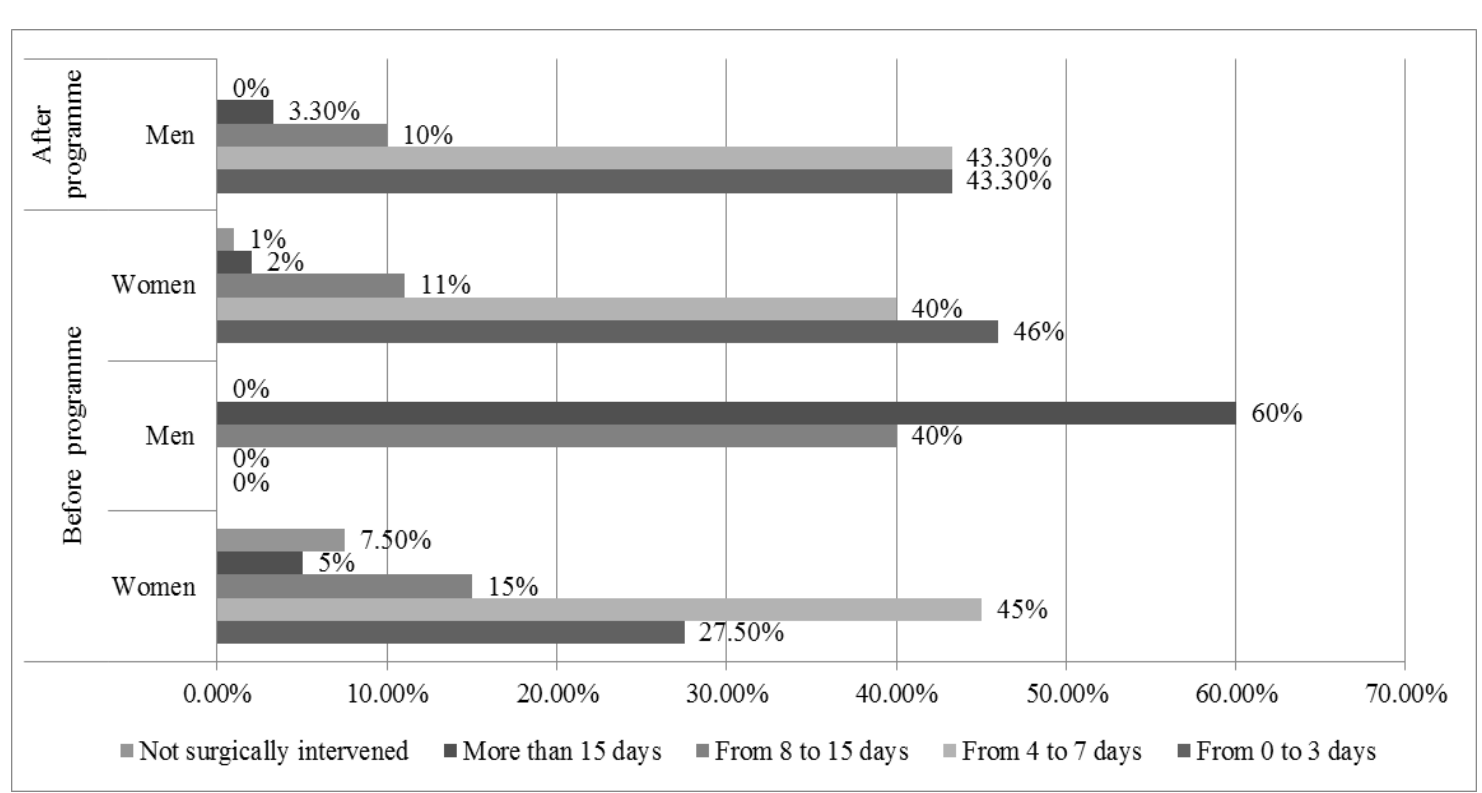

Figure 3. Waiting period up to the moment of the intervention according to gender

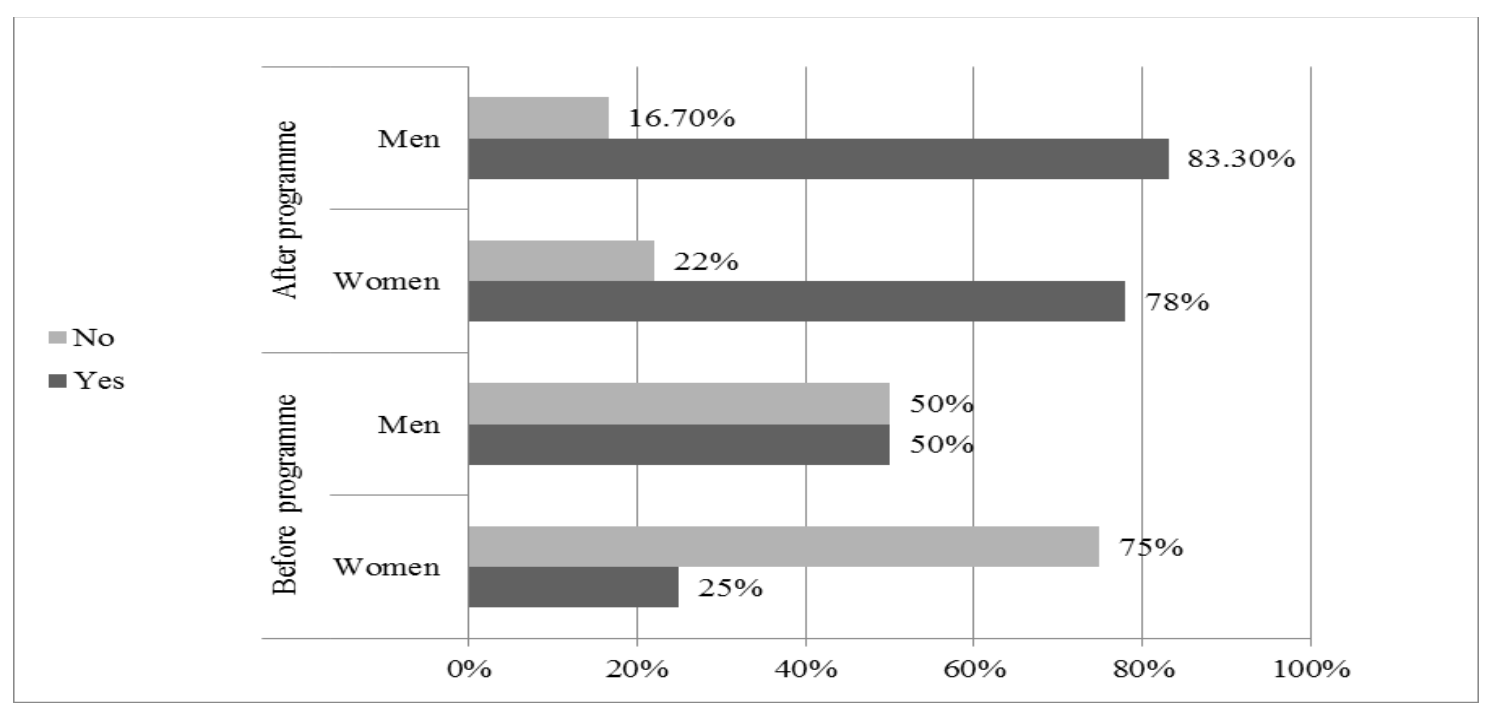

Figure 4. Prescription of the rehabilitation process after the intervention

Before the implementation of the programme, $60 \%$ of women had to wait 4 to 15 days, as opposed to $40 \%$ of men. After its implementation, $86 \%$ of men and women underwent surgery between the first and seventh day of hospitalisation. Moreover, the average waiting time decreased from 5.89 days to 3.62 days.

We could also observe that the prescription of the rehabilitation process after the surgical intervention has varied from $25 \%$ to $78 \%$ as regards women and from $50 \%$ to $83.3 \%$ in relation to men. See Figure 4 .

As regards the cross-sectional analysis, almost half of the women who were prescribed rehabilitation were assisted in the Orthogeriatric Unit, as opposed to $60 \%$ of men, whereas $14 \%$ underwent outpatient rehabilitation and $15 \%$ underwent inpatient rehabilitation at home. $24 \%$ of men underwent outpatient rehabilitation whereas $16 \%$ of them underwent inpatient rehabilitation at home.

Regarding the waiting period from the surgical intervention to the transfer to OU we could observe that more than $60 \%$ of women had to wait 6 to 10 days and more than $20 \%$ had to wait 11 to 15 days. Only $8 \%$ had to wait 1 to 5 days and $2 \%$ waited more than 20 days. The average waiting time for women was 9.10 days. In relation to men, more than $70 \%$ of them had to wait between 6 and 10 days, $11 \%$ waited between 0 and 5 days and $11 \%$ between 16 and 20 days. The average waiting time for men was 7.71 days.

With respect to the waiting period from the hospital admission to the request for a social care assessment, $60 \%$ of women had to wait 0 to 1 day whereas $37 \%$ of women had to wait 2 to 10 days, and the average waiting time was 2.55 days. The average waiting time for was slightly lower than that of women (2.33 days). 


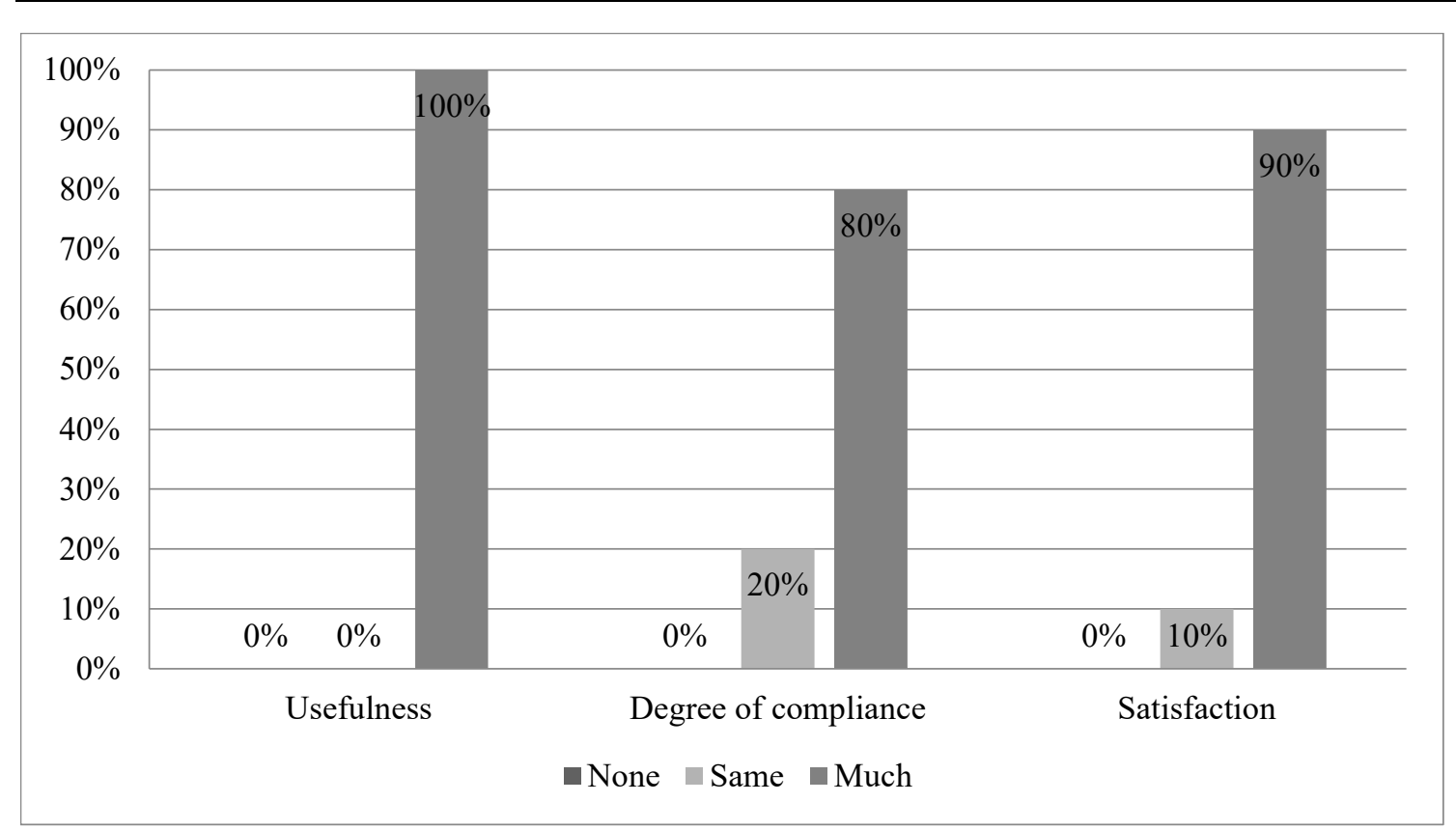

Figure 5. Assessment performed by professionals

Table 3. Aspects to improve and to maintain

\begin{tabular}{|c|c|}
\hline Aspects to improve (weaknesses) & Aspects to maintain (strengths) \\
\hline $\begin{array}{l}\text { Communication among professionals. } \\
\text { Joint decision-making on the part of those professionals } \\
\text { involved. } \\
\text { Consolidation of team meetings. } \\
\text { Visibility of the programme in the hospital. } \\
\text { Limited involvement of the hospital managers and directors. } \\
\text { Follow-up of the patient's progress after being discharged } \\
\text { from hospital and rehabilitation. } \\
\text { Lack of awareness of the importance of this kind of } \\
\text { programme. }\end{array}$ & $\begin{array}{l}\text { The programme. It benefits the patient, his/her family and the } \\
\text { hospital. } \\
\text { Coordination team meetings. } \\
\text { IT support for communication through DRAGO application. } \\
\text { Multidisciplinarity of the team and comprehensive approach } \\
\text { focused on attention. } \\
\text { Support to the family or to the caregiver. } \\
\text { Analysis of the previous life of the patient. It allows us to return } \\
\text { him/her to his/her environment trying to keep his/her previous } \\
\text { abilities. }\end{array}$ \\
\hline
\end{tabular}

With regard to the days the patients were hospitalised in the Orthogeriatric Unit, we could observe that $51 \%$ of women were in the unit from 1 to 10 days, whereas more than $23 \%$ stayed there more than 25 days, and the average length of stay in hospital was 23.40 days. Nevertheless, we can state that $48 \%$ of men spent between 1 and 15 days, and only $12 \%$ were in hospital more than 25 days, and the average length of stay in hospital was 17.82 days.

\section{Results of the Sample of Professionals}

This section shows the results obtained after the assessment performed by the professionals involved in the implementation of the programme. See Figure 5.

Taking into account the professional experience of those who have participated in the Orthogeriatrics Programme in UHNSC, we can state that all of them found it a useful device due to the results obtained. In this sense, they stated that "it improves the quality of patient care when they return home..." (P1) and (P3) since it enables "the patient's recovery from a global approach..." (P5), (P2) and (P7). As regards the degree of compliance with the programme, we could observe a high level of satisfaction, although some professionals pointed out the need to improve "...the coordination among the members of the team, especially at a medical and rehabilitation level..." (P1), (P3) and (P4), “...the degree of knowledge of some professionals about the programme" (P5) and (P6), and the fulfilment of "...the time spent in the established procedures" (P1), (P4) and (P7). Furthermore, all the professionals in the unit unanimously expressed the need to improve the processes of "communication among those professionals involved".

Regarding the general level of satisfaction with the programme, we can argue that it was very high. However, we could note in the detailed analysis of the answers given by professionals a need to reflect on the issues they have considered as weaknesses and strengths of the programme. See Table 3. 


\section{DISCUSSION}

Research has shown that this kind of programme allows us to obtain better results as regards both the period of the patient's hospitalisation and the waiting period before the surgical intervention (Miura, Di Piero, \& Homer, 2009; Sierra et al., 2017). Our research, like other similar studies (González-Montalvo et al., 2009; Sierra et al., 2017), has achieved a reduction in the patient's hospital stay.

There has also been an increase in the prescription of rehabilitation for patients who, being referred to SWU, were admitted to hospital for hip fracture. This upward trend has also been shown by studies such as that carried out by Cruz (2016) and Miura et al. (2009), related to the improvement in the implementation of this kind of programme focused on the patient's recovery. Patients who were admitted to OU in UHNSC were able to walk at the end of their hospital stay, experiencing a functional improvement at hospital discharge (Montalvo et al., 2011). With the implementation of the programme, both the waiting period from the hospital admission up to the surgical intervention and the discharges in social-health centres (SHC) have decreased. Moreover, patients have undergone more rehabilitation sessions (Geriatrics and Gerontology Spanish Society, 2007). This fact allows them to recover mobility and functionality before returning home.

This has been possible due to early commencement of the rehabilitation sessions, which have improved mobility and autonomy, resulting in greater independence in the activities of daily life. These patient rehabilitation processes have, as shown by the findings of this study, reduced the length of hospital stay (Marrero and Lillo-Crespo, 2015; Sierra et al., 2017), which translates into a lower risk of potential complications from surgical interventions (Mortimore et al., 2008) and from prolonged length of stay (Suárez et al., 2017).

The implementation of the Orthogeriatrics Programme in UHNSC has allowed us to decrease the waiting period from the surgical intervention to the start of the rehabilitation process in those patients who are admitted to hospital due to a hip fracture and are referred to the Orthogeriatric Unit. This waiting period has become significantly lower to the amount of time a patient waits to receive outpatient rehabilitation (Falcón, 2014).

Nevertheless, those patients who were admitted for hip fracture and who were referred to SWU are hospitalised in the unit more days than expected. Perhaps the fact that some patients have multiple pathologies, apart from the specific characteristics of each fracture, may be the reason for the delay in their recovery.

Furthermore, we have proven that there is a lag in the time estimated by traumatologists to request the social care assessment of patients who are admitted to hospital due to a hip fracture. These cases are referred to SWU. Interconsultations in the Traumatology Service are not performed the same day the patient is admitted to hospital, once they are verified and fulfil the admission criteria in the programme. This fact delays the social assessment performed by SWU. This situation is perhaps an evidence of the lack of communication and coordination expressed by some professionals, an urgent need according to the professionals who voluntarily participated in this study.

\section{CONCLUSIONS}

The assessment of the Orthogeriatrics Programme in UHNSC has allowed us to reach the following conclusions:

In relation to the patient's profile, the average age of the women who received care was 83 years, which has direct implications since increased longevity - according to latest research Spain and Japan now have the longest life expectancy - will mean that public and private healthcare have to adapt their services and facilities to this new phenomenon.

Most of them lived alone or with their children. They received good informal support and almost half of them had previous formal support but we must prevent and anticipate those situations where their family are unable to offer them the attention that they require.

As regards male patients, their mean age was 76 years. More than half of these patients lived with their spouses and/or children. They received good informal support and most of them had no previous formal support, and consideration must be given to a health education that breaks down stereotypes and social prejudice. It is far more common for women to help each other than it is for men.

Regarding the longitudinal analysis, we can state that the days of hospitalisation decreased significantly from $52.5 \%$ of women who were in hospital from 16 to 30 days to $73 \%$ of women who were hospitalised between 1 and 15 days. $60 \%$ of men were hospitalised between 11 and 20 days, and almost $85 \%$ were in hospital between 1 and 15 days. Likewise, the number of surgical interventions also increased after the implementation of the programme (from $92.5 \%$ to $99 \%$ surgical interventions in women and from $90 \%$ to $100 \%$ surgical interventions in men). The obvious conclusion is that we need more planning and greater streamlining to make full use of human and financial resources in both public and private healthcare provision.

The waiting period from the hospital admission up to the moment of the surgical intervention decreased after the creation of the programme. Before its implementation, $60 \%$ of women had to wait 4 to 15 days and, at present, 
$86 \%$ are surgically intervened between the first and seventh day after their hospital admission. $60 \%$ of men had to wait more than 15 days. However, after the implementation of the programme, almost $87 \%$ waited 1 to 7 days.

Moreover, there has also been an increase in prescription of the rehabilitation process after the surgical intervention. Before the implementation of the programme, only $25 \%$ of women were prescribed rehabilitation. However, after its introduction, $78 \%$ of women received rehabilitation. As regards men, there was an increase from $50 \%$ to $85 \%$. In short, and in all respects, there are undoubted advantages in performing rehabilitation with the least possible delay because it means a more cost-effective use - in human and professional terms - of services without having to increase the number of professionals.

The most relevant finding is that multidisciplinary cooperation between healthcare and education professionals can improve treatments provided by public healthcare services. Early rehabilitation reduces costs considerably and creates positive future expectations in the care of older people, whose numbers are on the rise throughout Europe, especially in Spain, where average life expectancy is increasing. This has created a new field of work that brings together cooperation, solidarity and effectiveness in the treatment of common health problems.

We should also point out a gender-related fact that clearly gives the lie to what have been called "gender-blind" professional practices: the majority of those who benefit are women, since their lifestyle entails fewer risks.

\section{REFERENCES}

Agency for Clinical Innovation (2010). The orthogeriatric model of care: Clinical practice guide 2010. Australia: Agency for Clinical Innovation.

Alonso, E., Pozo, C., \& Martos, M.J. (2008). Intervención psicosocial y evaluación de programas en el ámbito de la salud. Jaén, Spain: Formación Alcalá.

Bardales, Y., González, J. I., Abizanda, P., \& Alarcón, M. T. (2012). Guías clínicas de fractura de cadera. Comparación de sus principales recomendaciones. Revista española de geriatría y gerontología, 47(5), 220-227. https:/ / doi.org/10.1016/j.regg.2012.02.014

Barragán, F. (2016). Present-Absent Older people in the family. Elderly Women in the Family: The Ethics of Care. Polish Social Gerontology Journal 2(12), 25-31. Retrieved from https:/ /www.researchgate.net/profile/Artur_Fabis/publication/326011056_Family_joys_and_worries_i n_the_existential_reflections_of_people_in_their_late_adulthood_A_qualitative_research_report/links/5b 337d7ea6fdcc8506d197cc/Family-joys-and-worries-in-the-existential-reflections-of-people-in-their-lateadulthood-A-qualitative-research-report.pdf\#page $=25$

Baztán, J., Suárez, F., \& García, F. (2004). Informe sobre la necesidad de unidades de agudos y unidades geriátricas de recuperación funcional como parte de los recursos hospitalarios especializados para personas mayores. Madrid, Spain: SEMEG.

Berman, P. W., O`Nam, B. A., \& Floyd, W. (1981). The double standard of aging and the social situation, Sex Roles, (7), 87-96. Retrieved from https:/ /link.springer.com/article/10.1007/BF00287795

Cánovas, F., \& Pardavila, B. (coord.) (2004) La gestión de la calidad en los Servicios Sociales. Madrid, Spain: Ministerio de Trabajo y Asuntos Sociales.

Ceballos, R. (2010). Dirección y gestión de residencias geriátricas. Jaén, Spain: Formación Alcalá.

Cruz, M. C., \& Lillo, M. (2015). Implantación de una Unidad de Ortogeriatría en un hospital de tercer nivel. EJIHPE: European Journal of Investigation in Health, Psychology and Education, 5(1), 43-53. https:// doi.org/10.1989/ejihpe.v1i1.89

Cruz, M. D. L. Á. (2016). Análisis costo efectividad de la fisioterapia domiciliaria en pacientes intervenidos de prótesis de cadera. Hospital Universitario Nuestra Señora de la Candelaria de Santa Cruz de Tenerife (tesis doctoral). Universidad de Alicante, Alicante, Spain. Retrieved from https:/ / rua.ua.es/dspace/bitstream/10045/54308/1/tesis_cruz_marrero.pdf

Department of Health of the Government of Western Australia (2008). Retrieved from https:/ / www.health.gov.au/internet/budget/publishing.nsf/Content/ABB1A12B5327F9D2CA257CA000 3FF55F/\$File/State-Info-Sheet-WA.pdf

Europa Press (2009). La Unidad de Ortogeriatría del Hospital La Paz acelera la recuperación de los ancianos con fractura de cadera. Retrieved from https://www.infosalus.com/asistencia/noticia-madrid-unidad-ortogeriatriahospital-paz-acelera-recuperacion-ancianos-fractura-cadera-20091106140317.html

Falcón, C. S. (2014). Análisis de resultados del Programa de Ortogeriatría del hospital Universitario Nuestra Señora de la Candelaria (Undergraduate Thesis). Universidad de La Laguna, Canarias, Spain. 
Fantova, F. (2005). Manual para la gestión de la intervención social. Políticas, organizaciones y sistemas para la acción. Madrid, Spain: CCS. Retrieved from http://sid.usal.es/idocs/F8/FDO20522/sistemas_publicos.pdf

Fernández, T., \& Ares, A. (coords.) (2002). Servicios Sociales: dirección, gestión y planificación. Madrid, Spain: Alianza. Fernández, T., De Lorenzo, R., \& Vázquez, O. (eds.) (2012). Diccionario de Trabajo Social. Madrid, Spain: Alianza.

García, M. P., \& Martínez, P. (coords.) (2012). Guía práctica para la realización de Trabajos de Fin de Grado y Trabajos de Fin de Máster. Murcia, Spain: Edit.um.

Geriatrics and Gerontology Spanish Society. (2007). Retrieved from http://www.eugms.org/ourmembers/national-societies/spain-segg.html

González-Montalvo, J. I., Rodil, B. P., Álvarez, A. B., Alarcón, T. A., \& Gutiérrez, S. H. (2009). Eficiencia de las unidades geriátricas de agudos en los hospitales españoles. Revista española de geriatría y gerontologia, 44(4), 205-208. https:// doi.org/10.1016/j.regg.2008.12.003

Handoll, H. H. G., \& Sherrington, C. (2007). Estrategias de movilización después de la cirugía por fractura de cadera en adultos (Cochrane Review). La Biblioteca Cochrane Plus, 2. Retrieved from http://www.fisterra.com/guias2/cochrane/ab001704-es.htm

Herrera, J. M. (2012). Manual práctico para la gestión de organizaciones proveedoras de Servicios Sociales. La Laguna, Spain: Drago.

Hoeing, H., Sanford, J., Butterfield, T., Griffiths, P., Richardson, P., \& Hargraves, K. (2006). Development of a tele technology protocol for in-home rehabilitation. J Rehabil Res Dev. (JRRD), 43(2), 287-98. https:/ / doi.org/10.1682/JRRD.2004.07.0089

Hyde, S. J. (1995). Psicología de la mujer La otra mitad de la experiencia humana [Half the Human Experience. The Psychology of Women]. Madrid, Spain: Morata.

Justice European Comission (2015). Glossary, 11. Retrieved from https://ejustice.europa.eu/content_glossaries_and_terminology-119-en.do

Marrero, M. C., \& Lillo-Crespo, M. (2015). Implantación de una Unidad de Ortogeriatría en un hospital de tercer nivel. EJIHPE: European Journal of Investigation in Health, Psychology and Education, 5(1), 43-53. https:// doi.org/10.1989/ejihpe.v1i1.89

Martos, M., Pozo, C., \& Alonso E. (2010). Enfermedades crónicas y adherencia terapéutica. Relevancia del apoyo social. Almería: Universidad de Almería.

Miura, L. N., Di Piero, A. R., \& Homer, L. D. (2009). Effects of a geriatrician-led hip fracture program: improvements in clinical and economic outcomes. Journal of the American Geriatrics Society, 57(1), 159-167. https:// doi.org/10.1111/j.1532-5415.2008.02069.x

Montalvo, J. I. G., Pérez, P. G., Vega, A. M., Alarcón, T. A., de Linera, J. L. M. Á., Garay, E. G., Cimbrelo, E., \& Biarge, J. A. (2011). La unidad de ortogeriatría de agudos. Evaluación de su efecto en el curso clínico de los pacientes con fractura de cadera y estimación de su impacto económico. Revista Española de Geriatría y Gerontología, 46(4), 193-199. https:/ / doi.org/10.1016/j.regg.2011.02.004

Mortimore, E., Haselow, D., Dolan, M., Hawkes, W., Langenberg, P., Zimmerman, S. and Magaziner, J. (2008). Amount of social contact and hip fracture mortality. Journal of the American Geriatrics Society, 56(6), 10691074. https:/ / doi.org/10.1111/j.1532-5415.2008.01706.x

National Clinical Guideline Centre (2011).'The management of hip fracture in Adults'. NICE National Clinical Guideline Centre. Retrieved from https://www.nice.org.uk/guidance/cg124/evidence/full-guideline-pdf183081997

Ortiz, F. J., Vidán, M., Marañón, E., Álvarez, L., García, M. A., Alonso, M., Toledano, M., \& Serra, J. A. (2008). Evolución prospectiva de un programa de intervención geriátrica interdisciplinaria y secuencial en la recuperación funcional del anciano con fractura de cadera. Trauma Fundación MAPFRE, 19(1), 13-21. http://www.mapfre.com/fundacion/html/revistas/trauma/v19n1/pdf/02_02.pdf

Pajulammi, H. M., Pihlajamäki, H. K., Luukkaala, T. H., Jousmäki, J. J., \& Nuotio, M. S. (2017). Association of comprehensive geriatric assessment with quality-related care practices during implementation and development of an orthogeriatric hip fracture program. European Geriatric Medicine, 8(5-6), 424-429. https:// doi.org/10.1016/j.eurger.2017.06.002

Pereñíguez, M. D. (2012). Trabajo Social e investigación. La Práctica Basada en la Evidencia. TSMU Revista de Trabajo Social de Murcia, (17), 22-25. http:/ / repositorio.ucam.edu/handle/10952/3359

Pioli, G., Giusti, A., \& Barone, A. (2008). Orthogeriatric care for the elderly with hip fractures: where are we? Italy: Retrieved from Aging: Clinical and Experimental Research. 
Rebolloso, E., Fernández-Ramírez, B., \& Cantón, P. (2008). Evaluación de programas de intervención social. Madrid, Spain: Síntesis.

Sackett, D. L., Rosenberg, W. M., Gray, J. M., Haynes, R. B., \& Richardson, W. S. (1996). Evidence based medicine: what it is and what it isn't. Retrieved from https:/ / www.ncbi.nlm.nih.gov/pmc/articles/PMC2349778/pdf/bmj00524-0009.pdf

Sánchez-Ocaña (2010). Mil preguntas y respuestas sobre tu salud. Guía ilustrada de consulta para toda la familia. Barcelona, Spain: Ceac.

Sierra, T. P., Solis, J. R., Fernández, P. A., de Suso, M. T. G., \& Calvo, M. H. (2017). Intervención geriátrica en el anciano ingresado por fractura de cadera en el Hospital Universitario de Guadalajara: repercusión clínica, asistencial y económica. Revista Española de Geriatría y Gerontología, 52(1), 27-30. https:// doi.org/10.1016/j.regg.2016.02.001

Sociedad Española de Geriatría y Gerontología (2007). Guía de buena práctica clínica en Geriatría. Anciano afecto de fractura de cadera. Madrid, Spain: Elsevier. Retrieved from https://www.segg.es/media/descargas/ Acreditacion\%20de\%20Calidad\%20SEGG/Residencias/guia_fractura_cadera.pdf

Sontag, S. (1972). The double standard of aging. Saturday review, 39, 29-38. Retrieved from https://dialnet.unirioja.es/descarga/articulo/2901264.pdf

Suárez, S., Pesantez, R. F., Díaz, M. E., Sánchez, D., Tristancho, L. J., Vanegas, M. V., \& Olarte, C. M. (2017). Impact on hip fracture mortality after the establishment of an orthogeriatric care program in a Colombian hospital. Journal of aging and health, 29(3), 474-488. https:/ / doi.org/10.1177/0898264316636839

Tang, H. (2017). A study of the effect of knowledge management on organizational culture and organizational effectiveness in medicine and health sciences. Eurasia Journal of Mathematics, Science and Technology Education, 13(6), 1831-1845. https:/ / doi.org/10.12973/eurasia.2017.00700a

Vega-de Céniga, M., Allegue-Allegue, N., Bellmunt-Montoya, S., López-Espada, C., Riera-Vázquez, R., SolanichValldaura, T., \& Pardo-Pardo, J. (2009). Medicina basada en la evidencia: concepto y aplicación. Angiología, 61(1), 29-34. https:/ / doi.org/10.1016/S0003-3170(09)11004-0

Vizoso, F. J., \& Caballer, J. (2005). La medicina basada en la evidencia. En C. L. Sanz. (Ed.), Cuadernos de Psiquiatría Comunitaria. Salud mental basada en la evidencia (pp.25-33). Oviedo, España: Asociación Asturiana de Neuropsiquiatría y Salud Mental Profesionales de Salud Mental. Retrieved from http://aen.es/wpcontent/uploads/2009/04/Cuadernos5.1.pdf

\section{http://www.ejmste.com}

